\title{
New Interdisciplinary Science Course for First-Year Faculty of Science Students: Overview and Preliminary Results from the Pilot
}

\author{
Robert Cockcroft, Sarah L. Symons, Lori Goff, Kris Knorr, Sarah J. Robinson, \\ Geneviève van Wersch, Devra Charney, and Michael J. Farquharson \\ McMaster University
}

Transitioning to university can be a daunting endeavour, with student success dependent on a myriad of effects (Pascarella \& Terenzini, 2005). Understanding how to navigate university systems, who to meet, how to get help, how to study, and what goals to set can be hard to grasp (Valle et al., 2003). We provide an overview of the new interdisciplinary foundations course, which piloted in fall 2014, for first-year Faculty of Science students at McMaster University. This course provides a taste of research-based learning (Healey, Jenkins, \& Lea, 2014) and develops essential skills that are important for an undergraduate degree and future academic or career plans, exposes students to a wide range of departments and programs in the Faculty of Science, and invites students to reflect on their academic journey and how it may be changing as a result of the course. This customized approach intentionally teaches students how to locate and use institutional resources and the expectations that the institution has of its students, while offering opportunities to create networks of support essential for student success and retention (Kuh, Cruce, Shoup, Kinzie, \& Gonyea, 2008), and speaks to a number of considerations highlighted in the literature (e.g., Ambrose, Bridges, DiPietro, Lovett, \& Norman, 2010). Other factors considered include balancing the needs of the Faculty, the resources available, and the goals, demands, and interests of the students. In this paper, we describe the course's design, structure and implementation, key components of the course, support from upper-level science students, and preliminary pedagogical results, which assess its impact on and perception by students.

\section{Introduction}

$\mathrm{T}$ here is potential for students who transition from high school to university to fall short of what is expected of them, not because they are incapable, but simply because they are much less familiar with their new environment and how to work within its framework. For students to successfully navigate through their university experience, a wealth of skills, knowledge, experience, and a network of support and contacts are needed. This paper provides a preliminary assessment of the effectiveness of the firstyear, first-term course developed at McMaster University that helps science students prepare for their university careers and beyond by introducing students to the people, programs, resources, and attitudes that they will need.

There is a vast amount of research literature on the transition from high school to university and from level to level within university, best teaching practices, peer mentorship programs and how 
students can help one another through their university experiences, and interdisciplinary courses, programs, and critiques (see reviews by Chen, $\mathrm{Hsu}$, \& Wu, 2009; Franks et al., 2007; Knight, Lattuca, Kimball, \& Reason, 2013; Krometis, Clark, Gonzalez, \& Leslie, 2011; and Stone, Bollard, \& Harbor, 2009). We discuss some of this literature below - in particular, papers that recommend approaches to create such a first-year course as described above, that support students through their transition to university.

Kuh et al. (2008) explored the relationship between student behaviours and institutional practices that foster student success. These authors examined academic achievement and persistence to determine how students' engagement (as measured by the National Survey for Student Engagement; Kuh, 2001) during the first year of university can impact subsequent years of their degree and whether the effects of engagement differ according to factors such as socioeconomic background and prior academic achievement. They concluded that first-year grades and retention of students into their second year of university are positively related to student engagement within the first year, and that such engagement has an equalizing effect whereby students generally benefit, particularly students with lower incoming academic achievements or lower socioeconomic backgrounds receiving the greatest benefit. Kuh et al. (2008) advise institutions to adopt practices that provide students with a strong support system, including peer tutoring and mentoring, welldesigned learning communities in the classroom, opportunities to work collaboratively outside the classroom, and effective teaching practices.

Ambrose et al. (2010) echo these findings, explaining that learning is an activity that students have to do rather than a passive process by which information is transmitted to them. Ambrose et al (2010) advocate that learning is best supported when students' prior knowledge (or lack thereof) is considered, the intellectual and social environment of the classroom is designed to promote learning, students are taught how to organise their knowledge and motivate and manage their own learning, and students' ability to give and receive feedback is developed (and is given to students' application of these skills).

The number of first-year seminar or comprehensive orientation courses that are designed to "assist students in their academic and social development and in their transition to college" (Hunter \& Linder, 2005, pp. 275-276) has increased over the last three decades (Hollins, 2009; Padgett $\&$ Keup, 2011). In 2013, the University of British Columbia's (UBC's) Science 113 course "First-Year Seminar in Science" (Fox et al., 2013), was awarded the Society for Teaching \& Learning in Higher Education's Alan Blizzard Award. This award was established to "encourage, identify, and publicly recognize those whose exemplary collaboration in university teaching enhances student learning" ("STLHE - Alan Blizzard Award," n.d.). That a course designed to improve the transition for students into university won this award emphasizes the significance these courses can have on students' development.

One of the ways in which students are increasingly being engaged at higher-education institutes is through "research-based" curricula, where it is not just the instructor that is research-active but also the students (Healey et al., 2014). The latter may not be contributing to original research themselves, especially in their first year at university, but are instead researching to actively construct their understanding with knowledge that is new to themthrough research and inquiry. Healey et al. (2014) define a research-based curriculum to be one where students are engaged rather than being passive observers, and one that is less concerned with content but more focussed on the research processes and problems.

We report on a new interdisciplinary firstyear science course, which was piloted at McMaster University in fall 2014, that aims to support students in their transition from high school to university by incorporating the recommendations from the above authors, and by building on the successes of other similar courses, such as at UBC. The McMaster course engages and motivates students to build, organize, and manage their own knowledge through research-based activities, which we discuss in further detail in subsequent sections. We also highlight 
preliminary results from an associated pedagogical study, before ending with a discussion about how the course will proceed and plans for future work. McMaster University is a medium-sized Canadian university with approximately 25000 undergraduate and 4000 graduate students.

\section{New Interdisciplinary Science Course: General Overview}

The new McMaster first-year interdisciplinary course for Faculty of Science students is supported by undergraduate course developers, undergraduate peer mentors and graduate teaching assistants (TAs). We discuss each of these components below.

\section{First-Year Course for Faculty of Science Students}

This optional/elective course gives students a unique combination of opportunities specifically customized to help them, from the very beginning of their undergraduate degree, to navigate the academic institution in which the majority will spend the next 3-5 years of their lives. The specific student-centred learning objectives, aligned with the issues raised in the introduction, are listed in Table 1.

\section{Table 1}

\section{The learning objectives of the interdisciplinary foundations course}

1. To develop students' strategies and attitudes that will improve thinking, learning, communication, and other skills needed to succeed in university

2. To familiarize students with Faculty of Science programs, courses, resources and culture

3. To nurture students' exploration and initial decisions about their academic path for subsequent years

4. To familiarize students with campus resources, computing resources, and information resources

5. To develop students teamwork skills and build positive relationships with their student mentors and peers

6. To develop students' online learning portfolio which will help them identify and develop their personal learning goals

7. To enable students' self-reflective practice and their understanding of its utility in refining personal learning goals

8. To enable students' acceptance and respect, and develop their understanding that these are shared values of the McMaster community 
In the first offering (fall 2014), the course was taught by two instructors (SLS and MJF) with support from an instructional coordinator $(\mathrm{GvW})$, an interdisciplinary program administrator (SJR), 25 upper-level undergraduate peer mentors, and four graduate student TAs. 157 first-year undergraduate science students completed the course; of these 153 students passed and 4 students failed. We note that the maximum capacity of the course has not yet been determined, although the annual enrolment in Faculty of Science programs is approximately 1500 first-year undergraduates. Rather than space restrictions or instructor availability, we anticipate that the major constraint for course enrolment may be conflicts with mandatory first-year courses from all of the Faculty's disciplines.

There were four scheduled hours of course work per week. One of these was spent with the instructors as an entire class; the remaining three hours were used for tutorials with the peer mentors and/or the TAs. Eight tutorial sections each had fewer than 25 first-year students and were assigned two or three mentors. TAs were each responsible for the associated marking across two tutorial sections.

Class time with the instructor at the start and end of term informed students how to effectively use campus resources and introduced them to a number of skill-development activities, such as time and stress management, academic integrity, communication and teamwork, with the focus of each skill on the transition to university. Classes were followed by tutorials in which peer mentors designed sessions based on students' interests to explore some of these campus resources (the peer mentors were unaccompanied by the instructor).

During the central weeks of term time, students interacted with faculty members during introductory talks from various science disciplines that corresponded to departments within the Faculty (these were also recorded for students' future reference). This gave an opportunity for departments to showcase their subject area(s), to expose students to a variety of sciences and approaches to research and learning that they might not have otherwise seen, and to allow students to question or raise any concerns with faculty members directly. In this way, students familiarized themselves with Faculty of Science programs, courses, resources, expectations, cultures, and the wealth of potential career options available, and could explore and make initial informed decisions about their academic path in subsequent years. By discussing career prospects, we aim to make more visible the connections between academia and the workplace to help address the gap between what students know and their ability to apply it (Pascarella $\&$ Terenzini, 2005).

Student activities were designed to be accompanied by reflective practice throughout the course during weekly and end-of-term reflection exercises to help foster some of the skills outlined by Ambrose et al., (2010). These exercises fostered students' ability to organize their knowledge, manage their own learning by identifying and developing their own personal learning goals, and-in understanding more about reflection-gain a useful tool that they could continue to use throughout their undergraduate degree and beyond. Students received feedback on their submitted reflections at least once during the term from their TAs.

Students were assessed via three main components: weekly quizzes via a web-based coursemanagement system (30\%); deliverables associated with the tutorials ( $40 \%$; see below); and a written reflective piece $(30 \%)$. Online learning portfolios were incorporated into the course to allow students to track their progress in their academic learning experiences, and further allow them to reflect systematically and critically (Zubizarreta, 2004); to encourage self-exploration, dialogue, and critique (Michelson \& Mandell, 2004); to promote student ownership of learning (Tompkins \& PaquetteFrenette, 2010); and to make meaning from learning by connecting disparate experiences (Peet, 2010).

The McMaster and UBC courses are similar in that they both include specific-learning activities, reflections, and TA and faculty feedback. The major difference is that the tutorials in the UBC course are led by faculty members (Fox et al., 2013), whereas the McMaster tutorials are led primarily by peer mentors, without the presence of TAs or faculty. 


\section{Mini-Research Investigations: Design and Mentoring}

Mini-research investigations (MRIs) were an integral and central research-based component of this course, showing students a core function (i.e., research) of the Faculty to which they belong. We use the term "research based" in a similar manner to Healey et al., (2014), but also distinguish it from inquiry-based learning because students learned by doing researchtype activities and researched particular topics rather than particular questions. Our research-based learning approach allowed the MRIs to be more selfcontained within the time-spans allotted for student groups to work on their projects, and to make project deliverables more consistent and easier to specify. During these week-long interdisciplinary MRIs (see Table 2), students developed teamwork skills and built positive relationships and networks with peers and student mentors (both important aspects as outlined by Kuh et al., 2008) while further learning about material relevant to the MRIs. They took place

\section{Table 2}

A summary of the six mini-research investigations (MRIs) that were undertaken in the 2014 version of the first-year course. MRI 0 served as an exemplar for the students to become familiar with the MRI process. Assessments are via worksheets unless otherwise stated

\begin{tabular}{|c|l|l|}
\hline MRI & Title & Brief Description \\
\hline 0 & Bottom line on Line 9 & $\begin{array}{l}\text { Use of scientific articles and a geographic information system to form a valid } \\
\text { and sound opinion on a local environmental issue. Assessment: draft a letter } \\
\text { to government official or environmental organization either for or against } \\
\text { Line 9 (an aging pipeline that runs through southern Ontario and Québec). }\end{array}$ \\
\hline 1 & $\begin{array}{l}\text { How can science guide a } \\
\text { healthy lifestyle? }\end{array}$ & $\begin{array}{l}\text { Literature review within exercise physiology, nutrition, biochemistry, } \\
\text { genetics, and psychology on the issue of maintaining a healthy lifestyle, and } \\
\text { drawing connections between scientific disciplines. Assessment: "reading } \\
\text { guides" that emphasize strategies for reading scientific articles. }\end{array}$ \\
\hline 2 & $\begin{array}{l}\text { Where did all the carbon } \\
\text { go? }\end{array}$ & $\begin{array}{l}\text { Data handling, spreadsheet software and fieldwork to calculate carbon } \\
\text { storage in living systems. }\end{array}$ \\
\hline 4 & $\begin{array}{l}\text { Investigating the } \\
\text { unconscious mind }\end{array}$ & $\begin{array}{l}\text { Formulating a research hypothesis, identifying in/dependent variables, } \\
\text { considering control and confounding variables through the topic of } \\
\text { "subliminal messaging". Assessment: experimental variable worksheet and 5- } \\
\text { minute group presentation. }\end{array}$ \\
\hline 5 & $\begin{array}{l}\text { An exploration in time } \\
\text { media }\end{array}$ & $\begin{array}{l}\text { The scientific method applied to an experiment on time measurement and } \\
\text { perception of time. Assessment: propose, develop, and follow experimental } \\
\text { procedures. }\end{array}$ \\
\hline Orbiting bodies & $\begin{array}{l}\text { Identifying and critically evaluating different influences, presentation styles, } \\
\text { and perceptions of information in primary and secondary sources. }\end{array}$ \\
\hline challenges that astronauts experience during space flight. \\
\hline
\end{tabular}


during the tutorials and were aimed at scientific skill development in connection with a variety of scientific disciplines within the Faculty of Science. Skills developed in students included the ability to independently learn and research, critically think and problem solve, write both individually and collaboratively, orally present their research, manage project and personal time, communicate within teams, and lead teams.

To ensure that students were interested in and motivated by the topics under investigation, the MRIs were designed and developed by students under faculty supervision in an upper-level course prior to the start of the first-year course. The first-year students were supported as they worked through the MRIs by peer mentors who were students in a second upper-level course that ran parallel to the first-year course. As such, this second upper-level course was the practicum to the earlier upper-level course. The development of our senior undergraduates' ability to mentor first-year undergraduate students for academic success was informed by the literature (Terrion \& Leonard, 2007). Figure 1 shows a timeline of the three course offerings. The upper-level students who designed the MRIs were generally not the same upper-level students who mentored the students, but both courses had the same instructors (LG and KK).

During non-MRI weeks, peer mentors used tutorial time to further support first-year students. Peer mentors spent time answering questions or addressing concerns raised by the students, introducing topics that were deemed relevant based on their own experience (e.g., test and exam preparation, decreasing stress levels, program selection options for second year), or elaborated on the material from class. Preparation for these tutorials occurred as part of the mentorship course.

In addition to the upper-level students who were MRI designers and those who were mentors, two additional groups were involved in aspects of this course. Three undergraduate assistants helped to finalize the MRIs over the summer prior to the start of the first-year course (refer to Figure 1), and four graduate teaching assistants aided with part of the marking during the term.

\begin{tabular}{|c|c|c|}
\hline Jan 2014 & Apr 2014 & Sep 2014 \\
\hline \multirow{2}{*}{$\begin{array}{l}\text { Upper-level course to } \\
\text { design MRIs }\end{array}$} & \multirow{2}{*}{$\begin{array}{c}\text { Summer undergraduate } \\
\text { assistants finalized MRI } \\
\text { design }\end{array}$} & First-year course \\
\hline & & $\begin{array}{l}\text { Upper-level mentor } \\
\text { course }\end{array}$ \\
\hline
\end{tabular}

Figure 1

Timeline for the initial offerings of the first-year science course and the associated courses in which upper-level students designed and supported the mini-research investigations (MRIs) 


\section{Pedagogical Study: Overview and Initial Results}

\section{Overview}

Students in the first-year course were invited to participate in a pedagogical study led by two of the authors (RC and DC); this study was reviewed and approved by the university's ethics board. The study involved anonymous pre- and post-surveys (see Appendices 1 and 2, respectively) at the start and end of the fall term. Students self-generated a unique confidentiality code that allowed pre- and post-course surveys to be paired. Survey methodology was used to encourage participation from a broad sample of students.

Students from the entire Faculty of Science, not just those in the new first-year course, were invited to participate in the pre-survey. There were 125 responses in total; $103(65.6 \%)$ were from students in the new course and $22(1.5 \%)$ were not (there were 157 students in the new course and approximately 1500 students in the entire Faculty of Science first-year cohort). The pre-survey asked students for background information including selfreported high school grades, expectations for and reasons why they chose (or did not choose) to take this new course, what factors affected their decision for the program in which they were enrolled, and to rank their incoming skill set for a variety of skills such as presentation, independent learning, and time management. The current response rate of $1.5 \%$ from students not in the course is too low to attempt to draw any conclusions with confidence from a comparison between the two student populations. We will complete a more detailed analysis between the students enrolled in the new course and those who are not in a future publication, when, with more data from future course offerings where we will incentivise participation (e.g., through a prize draw), we will be able to report any differences with stronger statistical significance.

Only students in the new course were invited to participate in the post-survey, and we received 57 responses (36.3\%) of which 38 students (24.2\%) had completed both the pre- and post-surveys. The post- survey asked students about the following topic areas: their perceptions of the course, including which components they found most enjoyable versus those with most room for improvement, and whether or not they would recommend the course to others; whether or not the course had introduced them to new material, changed their intentions for their future at university, or changed their opinion about one of the disciplines; the benefits and challenges of the mentors and their roles in the course; and their outgoing skill set, based on the same set of skills listed in the pre-survey. Follow-up questions asked the students if they would be willing (i) to share their reflections with the researchers, and (ii) for the researchers to contact them in their future levels of their program to help determine the impact of this first-year course on their other courses.

\section{Highlights of Initial Results}

From the students who answered the post-survey, the response was very positive (see Figure 2): 92\% would take the course again if they were a student entering university for the first time, and 98\% would recommend the course to other incoming first-year Faculty of Science students.

Part of the reason why the first offering of this new course was well received by the students may be that students' expectations of the course (shown in Figure 3) aligned with what was delivered, and what was most enjoyed by the students (Figure 4).

There is much overlap between Figures 3 and 4. Learning about upper-year programs is among the top number of responses in both expectations and most enjoyable component. The introductory talks about the various departments within the Faculty of Science were also highly appreciated, and covered topics about which the students were hoping to learn; these included the various fields of science and different career paths. The mini-research investigations and group work under the guidance of peer mentors provided opportunities for students to learn several transferable skills (as detailed in the MRI section), to gain experience with research, and to practice their ability to communicate. 


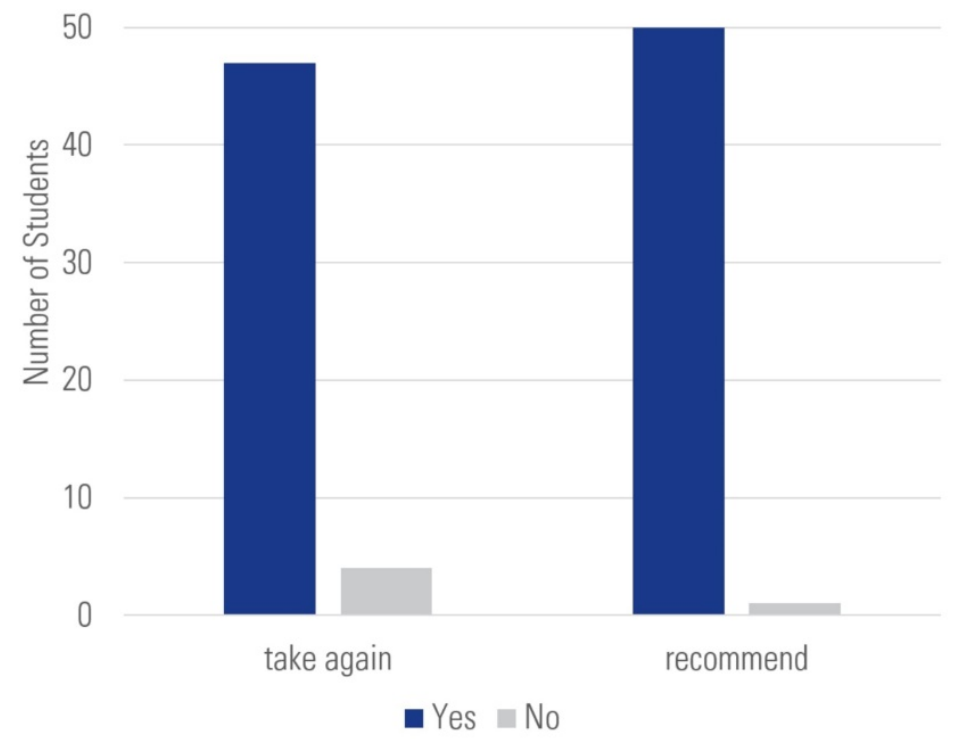

Figure 2

Responses to the post-survey questions [left] "If you were a student entering SCIENCE 1A03** for the first time, would you take this course again now knowing what you know?" and [right] "Would you recommend this course to other incoming first-year Faculty of Science students?" **SCIENCE $1 A 03$ is the code for the new interdisciplinary science course that is the focus of this paper

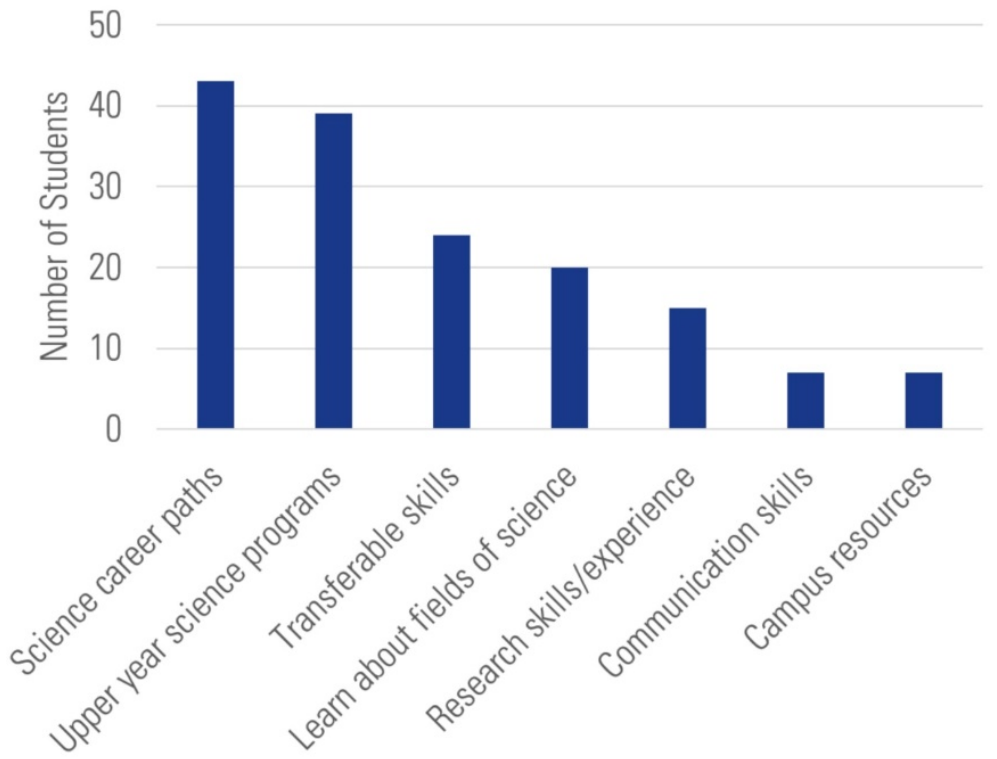

Figure 3

Responses to the pre-survey question "What are you hoping to take away with you after you complete this course?" This was an open-ended question, with students' responses grouped in the categories appearing along the horizontal axis. Each response could be included in more than one category. The responses are broadly split into two categories: increased knowledge and improved skill set. If the skill was specified by the student, such as "research skills" or "communication skills" these responses were coded separately from the broader "transferable skills" category, where we included students' terms "skills" (unspecified), "soft skills" and "transferable skills" 


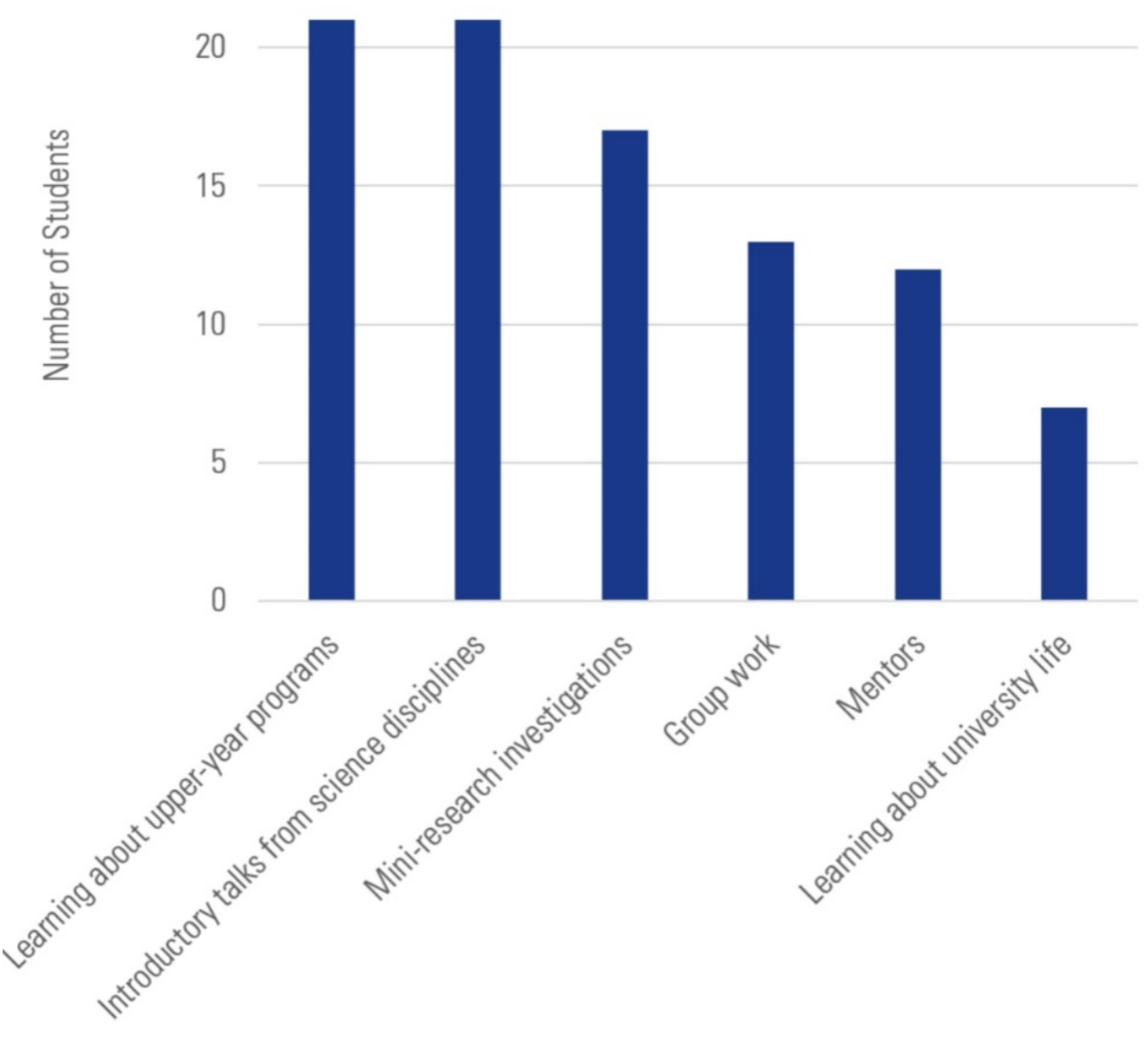

Figure 4

Responses to the post-survey question "Which course component has been the most enjoyable?" Similar to the question in Figure 3, this was an open-ended question

The following are two examples of responses from the open-ended question about the most enjoyable component:

"I found the 'introducing...' lectures to be the most enjoyable component of this course. It helped me choose which program I would like to go into next year and gave me a glimpse of all the possible opportunities in that field,"
"I enjoyed the Mini Research Investigations the most because it engages one in various areas of science and gives an insight to that science that helps develop communication and teamwork skills."

Student peer mentors were also regarded as highly beneficial by most students on the post-survey, as shown in Figure 5.

and 


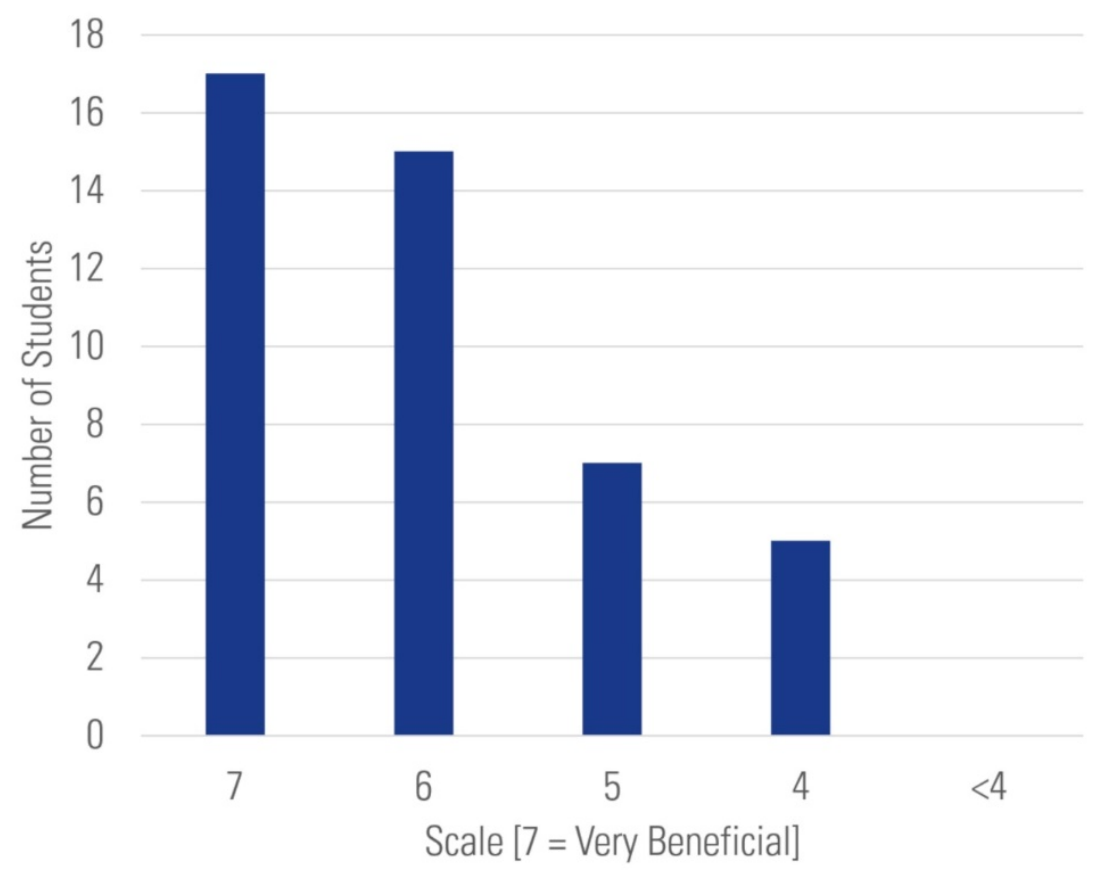

Figure 5

On a scale of 1-7, how beneficial were the peer mentors to your success this semester? [7 = Very Beneficial]

\section{Discussion: Next Steps}

After the successful first offering, the interdisciplinary foundations course will run again in fall 2015 at increased capacity of 275 students, with an associated increase in peer mentors (33) and TAs (6). Feedback from course evaluations, student reflections, and responses to the pedagogical survey has resulted in modifications to this second offering.

The course is not intended to be a blendedlearning course; however, in the previous year, there were a number of online components that were not well received by students based on the viewing statistics provided by the online learning management system, which hosted the materials. These online components were made as a general introduction to McMaster and its services, and their content covered current research on approaches to learning, library resources, academic advising, the student science society, and stress and time management. These components were not used by the students either because the same information was given to them repeatedly in the first few weeks of term or, unless there was an immediate need for the information, the students did not deem them necessary or useful. It is also possible that students in the first term do not yet understand how to integrate online material into their study regime. Conversations with faculty engaged in delivering fully blended learning courses in our Faculty suggest that our incoming students need guidance with how to approach blended materials. These components have been removed, and the class time will instead be increased from one to two hours per week allowing these components to be introduced by the instructors. The increased face-to-face time will also allow more skill-development activities and introductory talks from departments. However, we will also spend some class time discussing learning strategies and will include approaches to blended learning in this class material, as this should support students who are simultaneously engaged in blended learning courses. 
The number of MRIs will be reduced from six to five to allow an increase in time for peer mentors to choose their own mentoring topics (e.g., program selection, exam preparation). This reduction results from a request from both first-year students and peer mentors.

TAs will continue to assess student material in the course, but they will also introduce the MRIs and their associated assessments to the peer mentors. Peer mentors will continue to facilitate tutorials when students are working on their MRIs.

Now that the first cohort of both the firstyear students and upper-level mentors have completed their courses, it is possible to implement a progression of roles throughout a student's undergraduate degree - an aim which was intended from the inception of the course, but could not be realized until at least the second offering. After students have completed the first-year course, they will have the option during their second and third years to enrol in the peer mentorship course. Students in their fourth or fifth years who have previously been mentors will be able to apply to become a TA.

There are obvious advantages to such a progression. First-year students will benefit from having mentors and TAs who have direct experience with the course and will be able to relate to the students. It will also allow students who choose to go on to become peer mentors and TAs a chance to build on their experiences from their first year. It also helps instructors and course designers to delineate work that is appropriate for course work, such as the mentors do to improve their leadership skills, versus that for hired work, such as marking that TAs undertake. One concern was that there would not be enough interest from first-year students in becoming mentors; however, this has not been the case for the fall 2015 offering.

The pedagogical studies will continue, with more detailed analyses underway for the first offering of both the first-year course (RC and DC) and the upper-level mentorship course (LG and KK). This future analysis will combine research data from subsequent course offerings, compare high-school grades of those students in the new course and those who are not, track students' responses between the pre- and post-surveys to see how the course has influenced them, include an analysis of students' written reflections, and will incorporate follow-up studies with students from fall 2014 to explore how the course may have impacted their other studies.

\section{References}

Ambrose, S. A., Bridges, M. W., DiPietro, M., Lovett, M. C., \& Norman, M. K. (2010). How learning works: Seven research-based principles for smart teaching. San Francisco, CA: Jossey-Bass.

Chen, S., Hsu, I. C., \& Wu, C.-M. (2009). Evaluation of undergraduate curriculum reform for interdisciplinary learning. Teaching in Higher Education, 14(2), 161173. http://dx.doi.org/10.1080/135625109 02757203 VIEW ITEM

Fox, J., Birol, G., Han, A., Cassidy, A., Welsh, A., Nakonechny, J., Berger, J., Peacock, S., Samuels, L. (2014). 2013 Alan Blizzard Award feature article - Enriching educational experiences through UBC's first year seminar in science (SCIE113). Collected Essays on Learning and Teaching, 7(1), 1-18. Retrieved from http://celt.uwindsor.ca/ojs/leddy/index .php/CELT/article/view/4147 VIEW ITEM

Franks, D., Dale, P., Hindmarsh, R., Fellows, C., Buckridge, M., \& Cybinski, P. (2007). Interdisciplinary foundations: Reflecting on interdisciplinarity and three decades of teaching and research at Griffith University, Australia. Studies in Higher Education, 32(2), 167-185. http://dx.doi.org/10.1080/03075 070701267228 VIEW ITEM

Healey, M., Jenkins, A., \& Lea, J. (2014). Developing research-based curricula in college-based higher education. York, UK: The Higher Education Academy. 
Hollins, T. N. (2009). Examining the impact of a comprehensive approach to student orientation. Inquiry, 14(1), 15-27.

Hunter, M. A., \& Linder, C. W. (2005). First-year seminars. In Challenging and supporting the first-year student: $A$ handbook for improving the first year of college (pp. 275-276). San Francisco, CA: Jossey-Bass.

Knight, D. B., Lattuca, L. R., Kimball, E. W., \& Reason, R. D. (2013). Understanding interdisciplinarity: Curricular and organizational features of undergraduate interdisciplinary programs. Innovative Higher Education, 38(2), 143-158. http://dx.doi.org/10.1007/s10755-012-923 2-1 VIEW ITEM

Krometis, L.-A. H., Clark, E. P., Gonzalez, V., \& Leslie, M. E. (2011). The "death" of disciplines: Development of a team-taught course to provide an interdisciplinary perspective for first-year students. College Teaching, 59(2), 73-78. http://dx.doi.org/ 10.1080/87567555.2010.538765 VIEW ITEM

Kuh, G. D. (2001). Assessing what really matters to student learning inside the National Survey of Student Engagement. The Magazine of Higher Education, 33(3), 10-17.

Kuh, G. D., Cruce, T. M., Shoup, R., Kinzie, J., \& Gonyea, R. M. (2008). Unmasking the effects of student engagement on first-year college grades and persistence. The Journal of Higher Education, 79(5), 540-563. http:// dx.doi.org/10.1353/jhe.0.0019 VIEW ITEM

Michelson, E., \& Mandell, A. (2004). Portfolio development and the assessment of prior learning. Sterling, VA: Stylus.

Padgett, R. D., \& Keup, J. R. (2011). 2009 National survey of first-year seminars: Ongoing efforts to support students in transition. Columbia, SC: University of South Carolina, National
Resource Center for The First-Year Experience and Students in Transition.

Pascarella, E. T., \& Terenzini, P. T. (2005). How college affects students: $A$ third decade of research. San Francisco, CA: Jossey-Bass.

Peet, M. (2010). The integrative knowledge portfolio process: A program guide for educating reflective practitioners and lifelong learners. MedEdPORTAL Publications, 6, 7892 Retrieved from https://www.mededportal. org/publication/7892 VIEW ITEM

STLHE - Alan Blizzard Award. (n.d.). VIEW ITEM

Stone, T., Bollard, K., \& Harbor, J. M. (2009). Launching interdisciplinary programs as college signature areas: An example. Innovative Higher Education, 34(5), 321329. http://dx.doi.org/10.1007/s10755-00 9-9119-y VIEW ITEM

Terrion, J. L., \& Leonard, D. (2007). A taxonomy of the characteristics of student peer mentors in higher education: findings from a literature review. Mentoring and Tutoring, 15(2), 149164.

Tompkins, M., \& Paquette-Frenette, D. (2010). Learning portfolio models in health regulatory colleges of Ontario, Canada. Journal of Continuing Education in the Health Professions, 30(1), 57-64. http://dx.doi.org/ 10.1002/chp.20057 VIEW ITEM

Valle, A., Cabanach, R. G., Núnez, J. C., GonzálezPienda, J., Rodríguez, S., \& Piñeiro, I. (2003). Multiple goals, motivation and academic learning. British Journal of Educational Psychology, 73(1), 71-87. http://dx.doi.org/10.1348/0007099037628 69923 VIEW ITEM

Zubizarreta, J. (2004). The learning portfolio: Reflective practice for improving student learning. Bolton, MA: Anker. 


\section{Acknowledgements}

The authors gratefully appreciate the careful and detailed feedback from the CELT editor and the three anonymous referees that helped improve the quality of this manuscript.

\section{Biographies}

Robert Cockcroft, PhD (referred to as RC in the paper) is a cross-appointed Postdoctoral Research Fellow in the McMaster Institute for Innovation and Excellence in Teaching and Learning and the Department of Physics and Astronomy, and instructor of physics and astronomy classes.

Sarah Symons, $\mathrm{PhD}$ (SLS) is a Teaching Professor in McMaster's Honours Integrated Science Program and co-instructor of SCIENCE 1A03. She has twelve years of experience in teaching, pedagogical research, curriculum design, and educational project management in Canada and the UK.

Lori Goff, PhD (LG) is the Manager of Program Enhancement within the McMaster Institute for Innovation and Excellence in Teaching and Learning. Her research interests are connected to curriculum review and quality assurance. She is currently exploring ways in which students can be engaged in curriculum development and quality assurance processes.

Kris Knorr, MEd (KK) is a Research Coordinator in the McMaster Institute for Innovation and Excellence in Teaching and Learning. He has worked in educational development since 2008. Current research projects include exploring motivators and barriers to participation in educational development and identifying best practices for community engaged education in large classes.

Sarah J Robinson, MSc (SJR) is Administrator of Interdisciplinary Programs in the Faculty of Science with a background in project management and program development. She works closely with students as an academic advisor and is the primary leader of a leadership certificate program offered to first year science students coupled with an upper year mentorship program.

Geneviève van Wersch $(\mathrm{GvW})$ is the Instructional Coordinator for the Integrated Science Program and SCIENCE 1A03 course at McMaster University. Her interdisciplinary background is in research and administration in academic, government, and industrial settings. She is the liaison between faculty, students and staff, and coordinates teaching, laboratory, and examination activities.

Devra Charney, BASc (Honours) (DC) is an alumna of Honours Arts \& Science and English at McMaster University. She was a Student Scholar for the McMaster Institute for Innovation and Excellence in Teaching and Learning and worked with RC between September 2014 and June 2015. She is currently at Queen's University in their Faculty of Law.

Michael Farquharson, PhD (MJF) is the Associate Dean (Academic) for the Faculty of Science and a Professor in the Department of Medical Physics and Applied Radiation Sciences. He is responsible for the undergraduate student experience in Science. His interests are in the transition of undergraduates from high school to university and the development of technology assisted learning. 


\section{Appendix A \\ Pre-Survey}

[SCIENCE 1A03 is the code for the new interdisciplinary science course that is the focus of this paper; the code appears throughout both the pre- and post-surveys.]

1. Please create your own nine-digit confidentiality code below. This will be used to associate any future surveys with your response to this survey, but it is a code known only to you. Please enter the following:

The first 3 letters of your mother's first name

[ ] [ ] [ ]

The first 3 letters of the month you were born

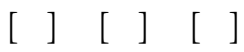

The first 3 letters of the street on which you live

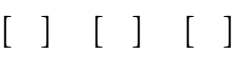

2. Are you:

? Male

?. Female

[? Do not identify as male or female (if you wish, please specify:

?] Prefer not to say

3. Is English your native language (or one of your native languages)?

? Yes

? $\mathrm{No}$

4. Are you entering McMaster University from:

[? Ontario

[? Elsewhere in Canada

?] Elsewhere in North America

?] Outside of North America

5. Are you entering your program from:

[? High school or equivalent

? College

? CEGEP

[? Other university program

? Work force

? Gap year

6. If you attended an Ontario high school, please answer this question. If not, please go to question 8 . What were your high school grades for the following courses? 


\begin{tabular}{|c|c|c|c|c|c|c|}
\hline \multirow[t]{2}{*}{ Grades } & \multicolumn{6}{|c|}{ Subject } \\
\hline & $\begin{array}{l}\text { ENG4U } \\
\text { (English) }\end{array}$ & $\begin{array}{l}\text { MCV4U } \\
\text { (Calculus } \\
\text { \& Vectors) }\end{array}$ & $\begin{array}{l}\text { MHF4U } \\
\text { (Advanced } \\
\text { Functions) }\end{array}$ & $\begin{array}{c}\text { SCH4U } \\
\text { (Chemistry) }\end{array}$ & $\begin{array}{l}\text { SPH4U } \\
\text { (Physics) }\end{array}$ & $\begin{array}{c}\text { SBI4U } \\
\text { (Biology) }\end{array}$ \\
\hline Did not take & $\mathrm{O}$ & $\mathrm{O}$ & $\mathrm{O}$ & $\mathrm{O}$ & $\mathrm{O}$ & $\mathrm{O}$ \\
\hline $90 \%-100 \%(\mathrm{~A}+)$ & $\mathrm{O}$ & $\mathrm{O}$ & $\mathrm{O}$ & $\mathrm{O}$ & $\mathrm{O}$ & $\mathrm{O}$ \\
\hline $84 \%-89 \%(\mathrm{~A})$ & $\mathrm{O}$ & $\mathrm{O}$ & $\mathrm{O}$ & $\mathrm{O}$ & $\mathrm{O}$ & $\mathrm{O}$ \\
\hline $80 \%-83 \%(\mathrm{~A}-)$ & $\mathrm{O}$ & $\mathrm{O}$ & $\mathrm{O}$ & $\mathrm{O}$ & $\mathrm{O}$ & $\mathrm{O}$ \\
\hline $77 \%-79 \%(\mathrm{~B}+)$ & $\mathrm{O}$ & $\mathrm{O}$ & $\mathrm{O}$ & $\mathrm{O}$ & $\mathrm{O}$ & $\mathrm{O}$ \\
\hline $73 \%-76 \%(\mathrm{~B})$ & $\mathrm{O}$ & $\mathrm{O}$ & $\mathrm{O}$ & $\mathrm{O}$ & $\mathrm{O}$ & $\mathrm{O}$ \\
\hline $70 \%-72 \%$ (B-) & $\mathrm{O}$ & $\mathrm{O}$ & $\mathrm{O}$ & $\mathrm{O}$ & $\mathrm{O}$ & $\mathrm{O}$ \\
\hline 67\%-69\% (C+) & $\mathrm{O}$ & $\mathrm{O}$ & $\mathrm{O}$ & $\mathrm{O}$ & $\mathrm{O}$ & $\mathrm{O}$ \\
\hline $63 \%-66 \%(\mathrm{C})$ & $\mathrm{O}$ & $\mathrm{O}$ & $\mathrm{O}$ & $\mathrm{O}$ & $\mathrm{O}$ & $\mathrm{O}$ \\
\hline $60 \%-62 \%(C-)$ & $\mathrm{O}$ & $\mathrm{O}$ & $\mathrm{O}$ & $\mathrm{O}$ & $\mathrm{O}$ & $\mathrm{O}$ \\
\hline $57 \%-59 \%(\mathrm{D}+)$ & $\mathrm{O}$ & $\mathrm{O}$ & $\mathrm{O}$ & $\mathrm{O}$ & $\mathrm{O}$ & $\mathrm{O}$ \\
\hline $53 \%-56 \%(\mathrm{D})$ & $\mathrm{O}$ & $\mathrm{O}$ & $\mathrm{O}$ & $\mathrm{O}$ & $\mathrm{O}$ & $\mathrm{O}$ \\
\hline $50 \%-52 \%$ (D-) & $\mathrm{O}$ & $\mathrm{O}$ & $\mathrm{O}$ & $\mathrm{O}$ & $\mathrm{O}$ & $\mathrm{O}$ \\
\hline $0 \%-49 \%(\mathrm{~F})$ & $\mathrm{O}$ & $\mathrm{O}$ & $\mathrm{O}$ & $\mathrm{O}$ & $\mathrm{O}$ & $\mathrm{O}$ \\
\hline
\end{tabular}

7. If you attended an Ontario high school, please answer this question. If not, please go to question 8 . List any other grade $12 \mathrm{U}$ courses that you completed, if applicable:

8. Are you taking the SCIENCE $1 \mathrm{~A} 03$ course?

? Yes ? Please go to question 9.

? No ? Please go to question 11. 
9. If you answered yes to question 8 (i.e., you are taking SCIENCE 1A03), please answer this question:

Why did you choose to enroll in SCIENCE 1A03?

(You may check more than one answer.)

[? I believe that this course will be useful for my undergraduate program and/or career.

[? The course outline sounded interesting.

? Many of my peers were taking this course and recommended it.

? It fits with my schedule.

[? I needed it to fill my credits.

[? Other; please expand:

10. If you answered yes to question 8 (i.e., you are taking SCIENCE 1A03), please answer this question: What are you hoping to take away with you after you complete this course?

11. If you answered no to question 8 (i.e., you are NOT taking SCIENCE 1A03), please answer this question: Why did you choose not to enroll in SCIENCE 1A03?

(You may check more than one answer.)

?] Course load was too full.

? SCIENCE $1 \mathrm{~A} 03$ conflicted with another course I wanted to take.

? SCIENCE $1 \mathrm{~A} 03$ was not appealing.

? Did not know about SCIENCE $1 \mathrm{~A} 03$.

?] Other; please expand:

12. What program are you in now?

?] Chemical and Physical Sciences I

[? Environmental and Earth Sciences I

[? Life Sciences I

?. Mathematics and Statistics I

[? Other: please specify: 
13. Why did you choose this program?

(You may choose more than one answer.)

? This program is the most interesting.

? This program will help me enter my chosen career.

[? Most of my peers recommended this program to be.

[? I am well suited to this program (i.e., I am good at the required subjects).

?] Other; please specify:

14. If you weren't in the program that you were currently in, what would be your second choice?

? Chemical and Physical Sciences I

[? Environmental and Earth Sciences I

? Life Sciences I

? Mathematics and Statistics I

[? Other: please specify:

15. Why would you choose this program?

\section{Questions 16-19 will depend on which program you are currently in:}

16. If you are NOT in the Chemical and Physical Sciences I program, why did you not choose this program?

17. If you are NOT in the Environmental and Earth Sciences I program, why did you not choose this program?

18. If you are NOT in the Life Sciences I program, why did you not choose this program? 
19. If you are NOT in the Mathematics and Statistics I program, why did you not choose this program?

20. For the following skills, what was your level of knowledge before coming to McMaster? Please indicate your knowledge according to the scale in the table.

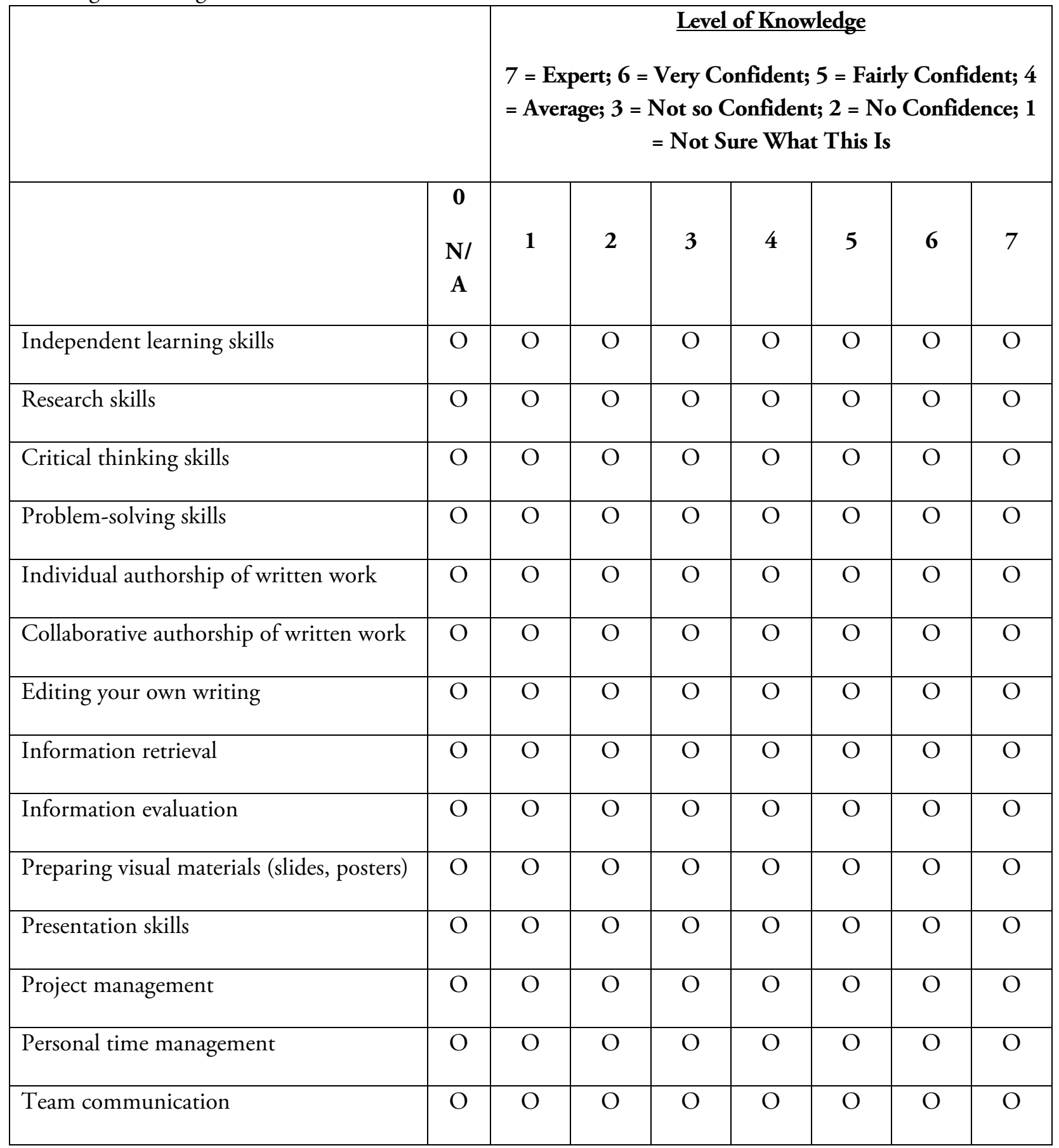




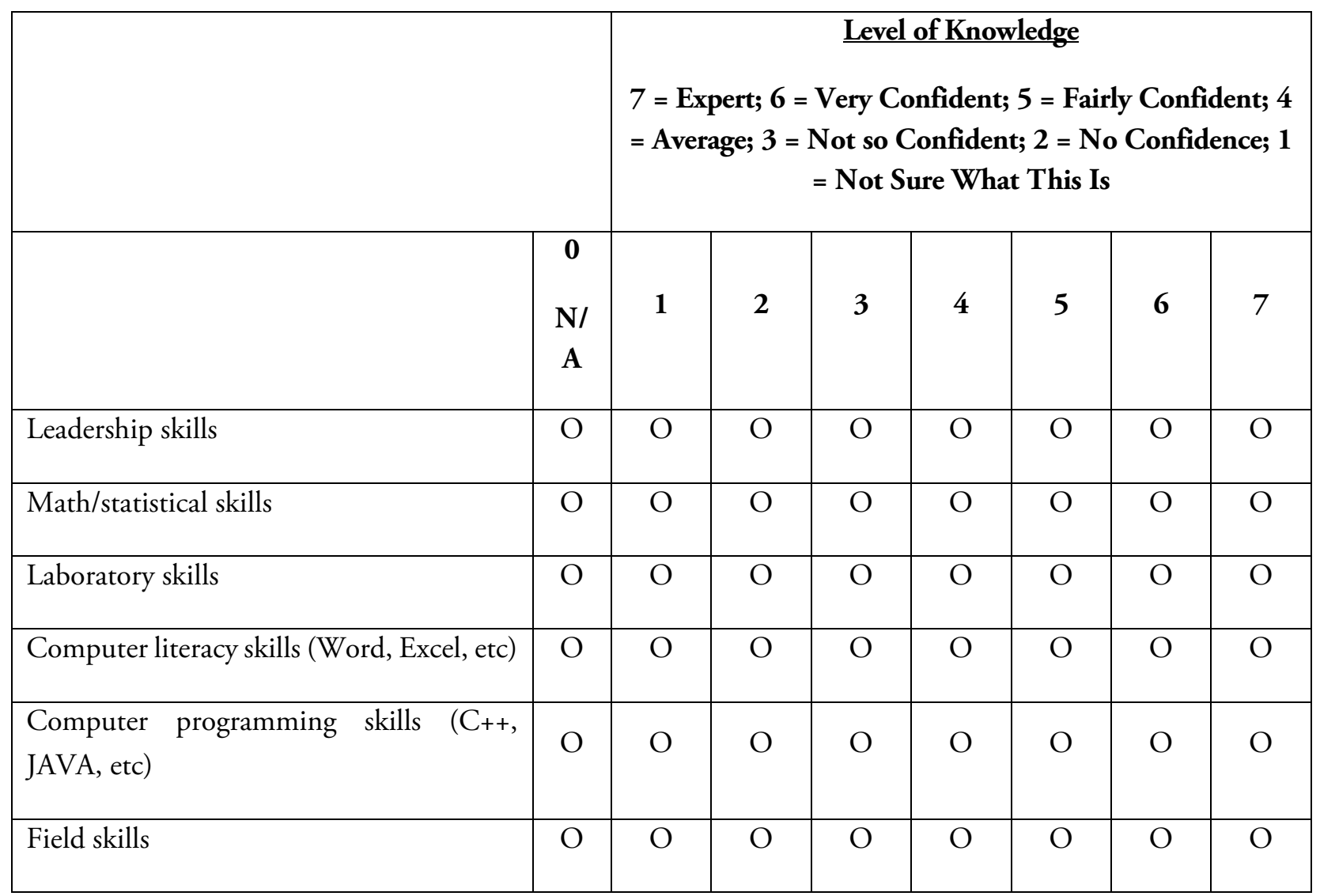

Thank you for taking part in this survey. Your answers are a valuable part of this research. 


\section{Appendix B \\ Post-Survey}

1. Please create your own nine-digit confidentiality code below. This will be used to associate any previous surveys with your response to this survey, but it is a code known only to you. Please enter the following:

The first 3 letters of your mother's first name

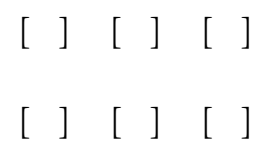

The first 3 letters of the month you were born

The first 3 letters of the street on which you live

2. On a scale of 1 to 7 , with 1 being the worst and 7 the best, how USEFUL has this course been?

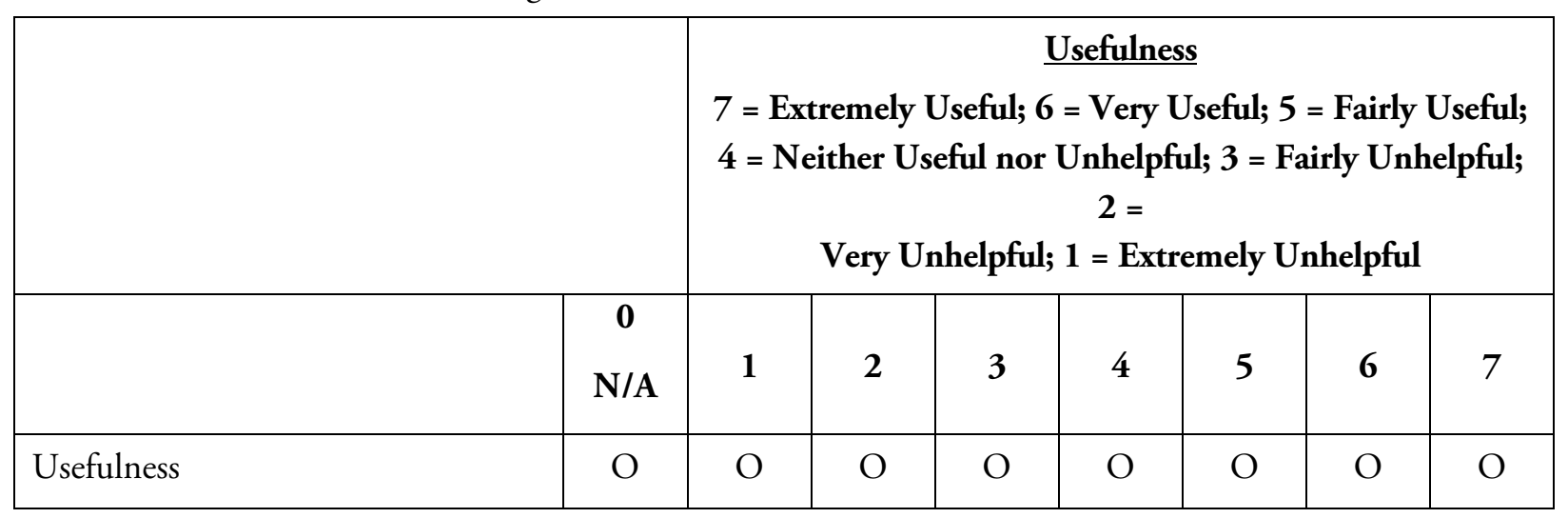

3. On a scale of 1 to 7 , with 1 being the worst and 7 the best, how ENJOYABLE has this course been?

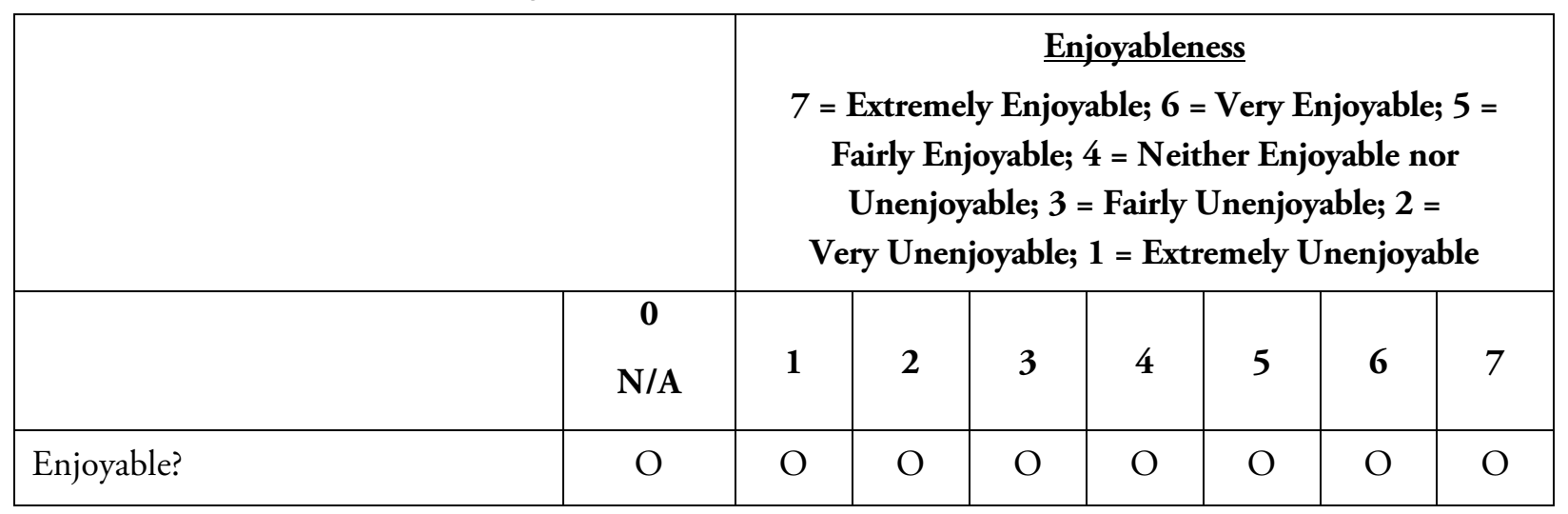


4. Which course component has been the most enjoyable, and why?

5. Which component has the most room for improvement, and why?

6. Overall, how much did you get out of the course compared to what you expected on a scale of 1 to 7 , with 1 representing "very much under expectations" and 7 "vastly exceeded expectations"?

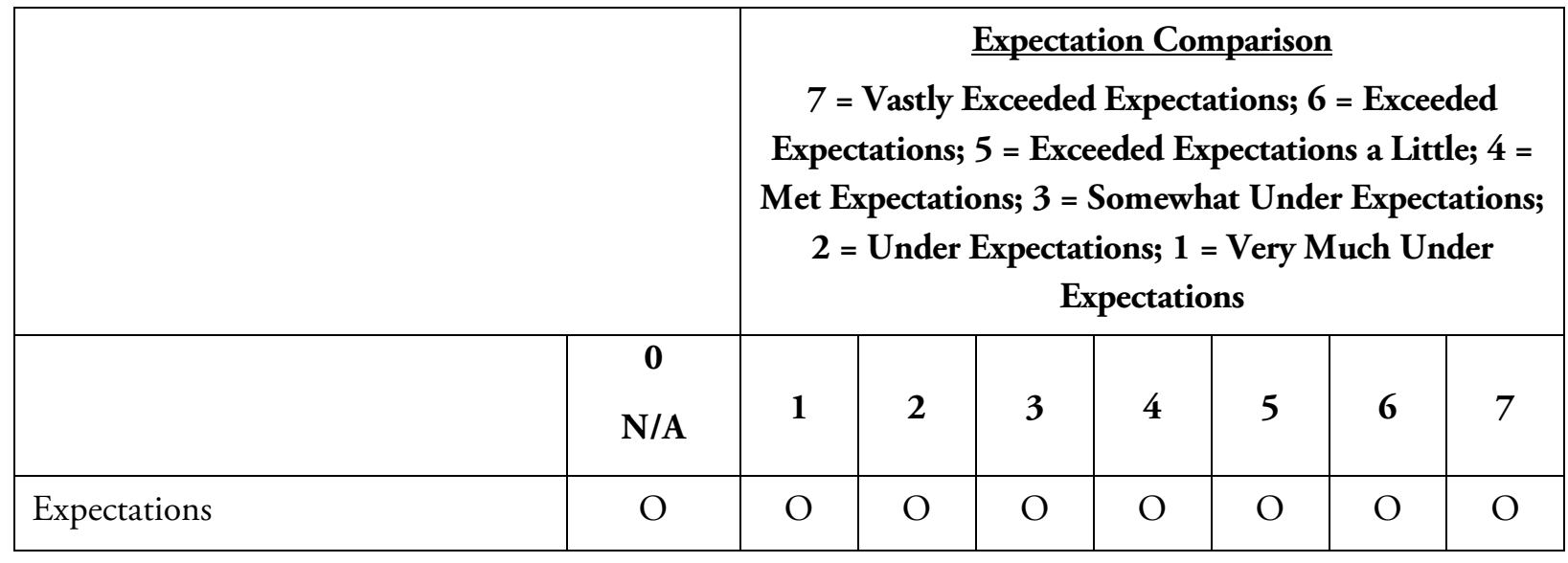

Please explain why you chose the above value: 
7. On a skill-by-skill basis, how much did you get out of the course compared to what you expected on a scale of 1 to 7 , with 1 representing "very much under expectations" and 7 "vastly exceeded expectations"?

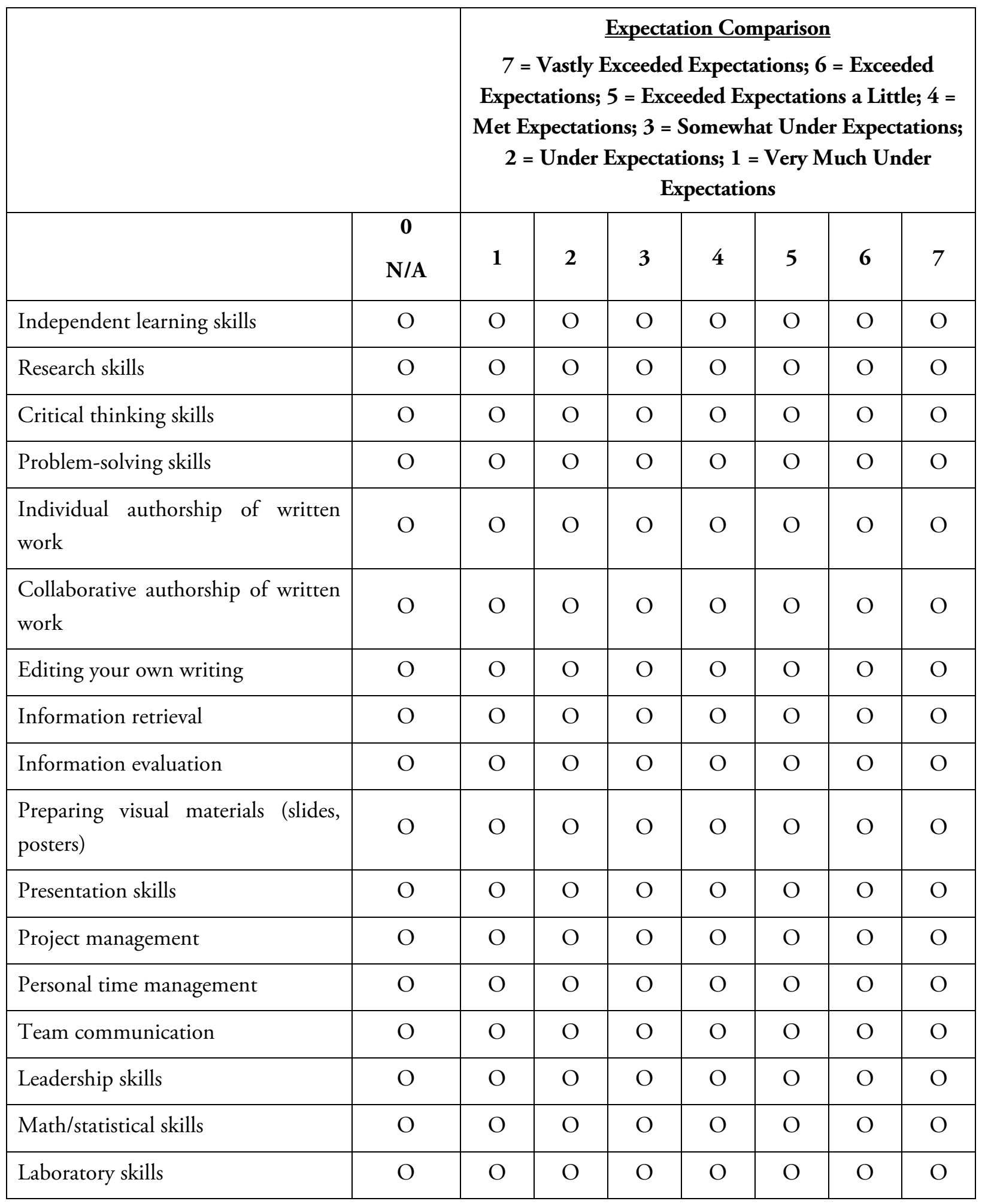




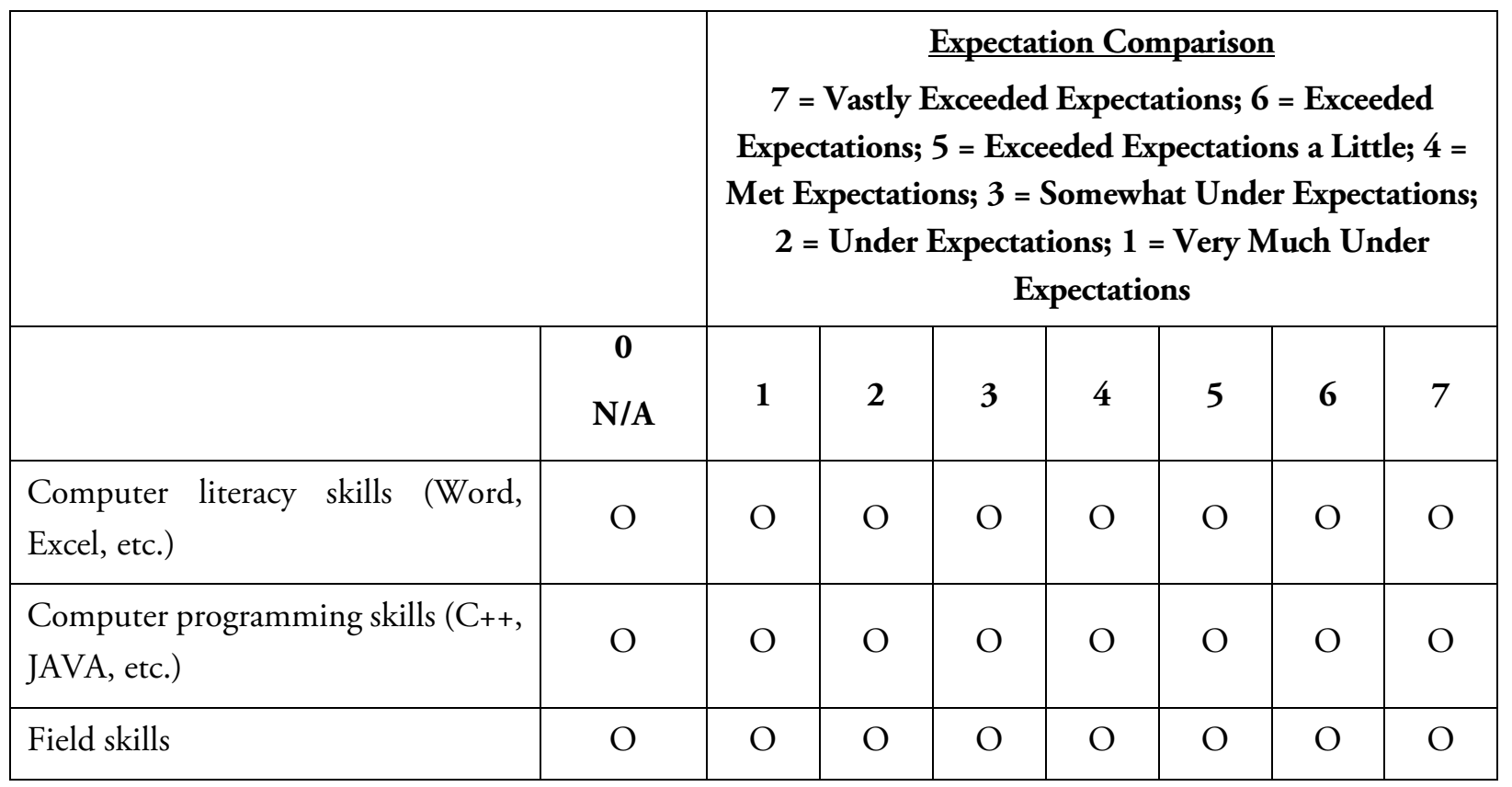

8. Have your intentions for what to do after completing this course changed compared to what you expected to do when you entered the course?

\begin{tabular}{|l|c|c|c|c|c|}
\hline \multicolumn{2}{|l|}{} & \multicolumn{3}{|c|}{$\begin{array}{c}\text { Intentions } \\
\mathbf{4} \text { = Changed Completely; 3 = } \\
\text { Changed a Lot; 2 = Changed a } \\
\text { Little; 1 = No Change }\end{array}$} \\
\hline & $\mathbf{0}$ & N/A & $\mathbf{1}$ & $\mathbf{3}$ & $\mathbf{4}$ \\
\hline $\begin{array}{l}\text { Now that you have almost completed this course, have your } \\
\text { future intentions changed compared to what you expected } \\
\text { to do when you entered the course? }\end{array}$ & O & O & O & O & O \\
\hline
\end{tabular}

Please explain: 
9. Have you encountered any subject material / topics of which you previously didn't know anything?

\begin{tabular}{|c|c|c|c|c|c|}
\hline & & $4=$ & $\begin{array}{l}\text { Nen } \\
\text { ythi } \\
\text { Littl }\end{array}$ & $\begin{array}{l}\text { teria } \\
=\mathrm{A} \\
=\mathrm{Nc}\end{array}$ & \\
\hline & $\begin{array}{c}\mathbf{0} \\
\text { N/A }\end{array}$ & 1 & 2 & 3 & 4 \\
\hline $\begin{array}{l}\text { Have you encountered any subject material / topics of } \\
\text { which you previously didn't know anything? }\end{array}$ & $\mathrm{O}$ & $\mathrm{O}$ & $\mathrm{O}$ & $\mathrm{O}$ & $\mathrm{O}$ \\
\hline
\end{tabular}

Please explain:

10. Has the way you think about any subject changed because of this course?

? $\mathrm{Yes}$

? $\mathrm{No}$

Please explain:

11. How do you see what you have learned in this course being applied to what you do for the rest of your undergraduate and/or future career? Please give an example(s):

12. If you were a student entering SCIENCE 1 A03 for the first time, would you take this course again now knowing what you know?
? Y Yes
[? No

Please explain: 
13. Would you recommend this course to other incoming first-year Faculty of Science students?
? $\mathrm{Yes}$
? $\mathrm{No}$

Please explain:

14. On a scale of 1-7, how BENEFICAL were the peer-mentors to your success this semester.

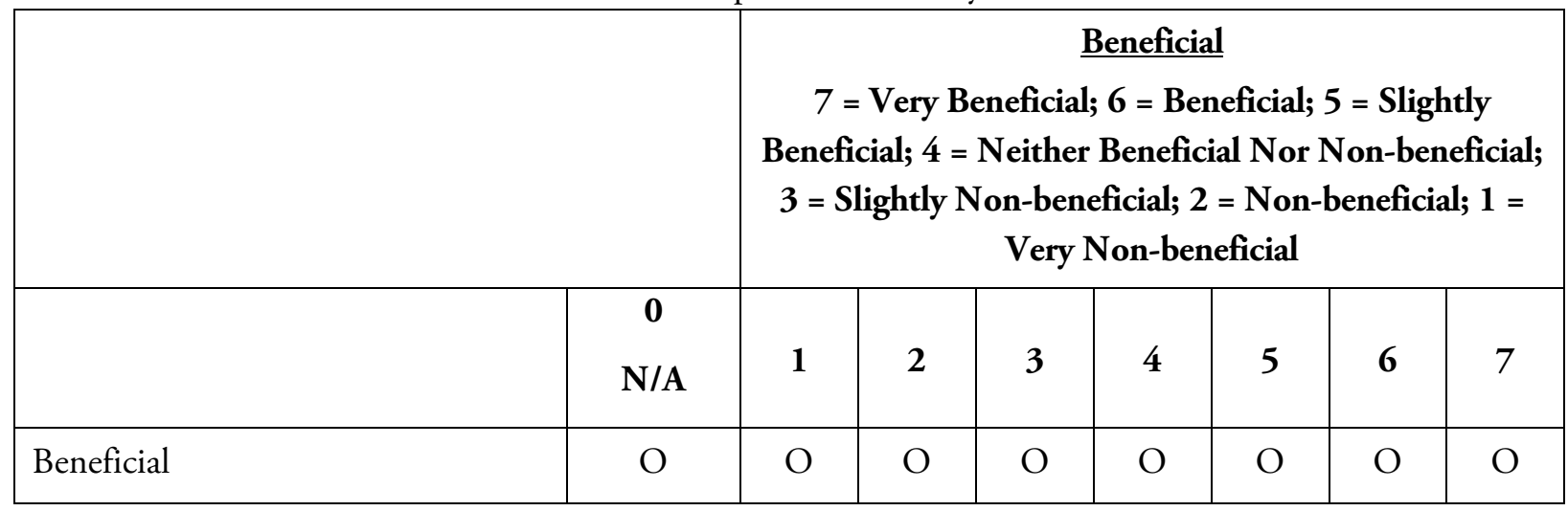

15. From your perspective, what were the benefits of having peer-mentors? Please explain:

16. What were the challenges associated with having peer-mentors? Please explain:

17. The peer-mentors were working to develop their own skills through the course. Did you notice development in any of your peer-mentors?

? $\mathrm{Yes}$

? $\mathrm{No}$

If yes, please describe and provide examples of this development: 
18. Do you have any other comments about the peer-mentors that you feel would be important to share? Please explain:

Thank you for taking part in this survey. Your answers are a valuable part of this research. 